Correspondence

Li-Ping Zhang

zhlping@hbu.edu.cn

\title{
Streptosporangium canum sp. nov., isolated from soil
}

\author{
Li-Ping Zhang, ${ }^{1,2}$ Li-Min Zhang ${ }^{1}$ and Xiu-Min Zhang ${ }^{1,2}$ \\ ${ }^{1}$ College of Life Sciences, Hebei University, Baoding 071002, PR China \\ ${ }^{2}$ The Key Laboratory of Microbial Diversity Research and Application of Hebei Province, Baoding \\ 071002, PR China
}

\begin{abstract}
An actinomycete strain, designated HBUM $170018^{\top}$, was isolated from soil from Hebei Province, China, and subjected to a polyphasic taxonomic analysis. This study included morphological and physiological investigations and analyses concerning cell chemistry, genomic DNA $\mathrm{G}+\mathrm{C}$ content, DNA-DNA hybridization and phylogeny. The data obtained were consistent with the assignment of strain HBUM $170018^{\top}$ to the genus Streptosporangium and were confirmed by the results of 16S rRNA gene sequence analysis. Strain HBUM $170018^{\top}$ can be differentiated from all Streptosporangium species with validly published names with reference to phenotypic characteristics, phylogenetic data and DNA-DNA hybridization results. On the basis of 16S rRNA gene sequencing, DNA-DNA hybridization and phenotypic data, strain HBUM $170018^{\top}$ represents a novel species of the genus Streptosporangium, for which the name Streptosporangium canum sp. nov. is proposed. The type strain is HBUM $170018^{\top}\left(=7177^{\top}\right.$ $=\mathrm{DSM} 45034^{\top}=$ CGMCC $4.2126^{\top}$ ).
\end{abstract}

The genus Streptosporangium was first described by Couch (1955). In most species of the genus, the aerial mycelium produces spherical sporangia that enclose non-motile sporangiospores. At the time of writing, there are 14 Streptosporangium species with validly published names: Streptosporangium roseum (Couch, 1955), S. amethystogenes, S. album, S. vulgare (Nonomura \& Ohara, 1960), S. longisporum (Schäfer, 1969), S. nondiastaticum, S. pseudovulgare (Nonomura \& Ohara, 1969), S. violaceochromogenes (Kawamoto et al., 1975), S. fragile (Shearer et al., 1983), S. carneum (Mertz \& Yao, 1990), S. claviforme (Petrolini et al., 1992), S. subroseum (Zhang et al., 2002), S. purpuratum and S. yunnanense (Zhang et al., 2005). S. amethystogenes has been divided into the subspecies $S$. amethystogenes subsp. amethystogenes (Nonomura \& Ohara, 1960) and S. amethystogenes subsp. fukuiense (Iinuma et al., 1996). With the development of science and technology, many novel taxa and novel valuable secondary metabolites have been discovered and increasing numbers of scientists are undertaking studies of extreme environments and unusual actinomycetes. Strain HBUM $170018^{\mathrm{T}}$ was isolated from a soil sample collected in Hebei Province, China, and was

The GenBank/EMBL/DDBJ accession number for the $16 \mathrm{~S}$ rRNA gene sequence of strain HBUM $170018^{\top}$ is AY996844.

Tables detailing the cultural characteristics of strain HBUM $170018^{\top}$ and levels of 16S rRNA gene sequence similarity and DNA-DNA reassociation between strain HBUM $170018^{\top}$ and related type strains are available as supplementary material with the online version of this paper. shown to produce spherical sporangia on the aerial mycelium. The results of this polyphasic taxonomic study indicated that this strain was distinct from known members of the genus Streptosporangium. Therefore, we consider that strain HBUM $170018^{\mathrm{T}}$ represents a novel species of the genus Streptosporangium.

Strain HBUM $170018^{\mathrm{T}}$ was cultured for 3, 5, 7 and 14 days on oatmeal agar (ISP3 medium; Shirling \& Gottlieb, 1966) at $28{ }^{\circ} \mathrm{C}$. Cells were cultured on glass bacteria-culture plates and microscope cover slips were inserted into the agar to examine the mycelial morphology. The strain was observed by using an Olympus light microscope (model BH-2) and an Amray scanning electron microscope (model KYKY-AMRAY 100B). Samples for scanning electron microscopy were prepared by cutting a block from an agar plate containing the strain, fixing the block in $2.5 \%$ glutaraldehyde at room temperature for $2 \mathrm{~h}$, washing it three times with $0.2 \mathrm{M}$ sodium phosphate buffer ( $\mathrm{pH}$ 7.2) for $10 \mathrm{~min}$ each time, fixing it once again in osmium tetroxide vapour for $4 \mathrm{~h}$ and then dehydrating the cells successively through $30,50,70,85,95$ and $100 \%$ ethanol (10 min each). Cultural characteristics were studied using cultures grown at $28{ }^{\circ} \mathrm{C}$ for 14 days on ISP3 medium, Bennett's agar (Jones, 1949), yeast extract-malt extract agar (ISP2 medium), glycerol-asparagine agar (ISP5 medium) and Czapek agar (Waksman, 1967). Colour determinations were made by comparing the culture with colour strips from the standard samples of the Research Group of Actinomycetes (1970). Strain HBUM $170018^{\mathrm{T}}$ grew well on 
various media. The strain produced aerial and vegetative hyphae of different colours on various media. The results are available in Supplementary Table S1 (available in IJSEM Online). No amethyst, diffusible pigments were produced on any of the media tested. Strain HBUM $170018^{\mathrm{T}}$ produced aerial mycelium bearing spherical sporangia (generally $3-6 \mu \mathrm{m}$ in diameter; Fig. 1) that produced non-motile sporangiospores.

To obtain biomass for chemotaxonomic analyses, cultures were grown in Bennett's broth for $5-7$ days at $28{ }^{\circ} \mathrm{C}$ on rotary shakers. When maximum growth was observed, the broth cultures were checked for purity, harvested by centrifugation and washed three times with distilled water. Amino acids from purified cell walls were analysed by using the methods of Lechevalier \& Lechevalier (1980). Diagnostic amino acids and sugars were determined from whole-cell hydrolysates using the methods of Becker et al. (1964). Phospholipids were obtained from freeze-dried biomass (approx. $100 \mathrm{mg}$ ) and analysed according to Lechevalier et al. (1981). Menaquinones (from $100 \mathrm{mg}$ freeze-dried biomass) were analysed as described previously by Collins (1985). Methyl esters of cellular fatty acids (from $10 \mathrm{mg}$ freeze-dried biomass) were determined as described by Miller (1982) and Kuykendall et al. (1988).

Purified cell walls of strain HBUM $170018^{\mathrm{T}}$ contained meso-diaminopimelic acid. Whole-cell hydrolysates contained madurose, glucose, ribose and rhamnose. On the basis of these data, the strain was considered to have a type III/B cell wall. The major menaquinones of the strain were MK-9 $\left(\mathrm{H}_{2}\right)$ and MK-9 $\left(\mathrm{H}_{4}\right)$. The predominant whole-cell fatty acids were $\mathrm{C}_{16: 0}(21.33 \%), \mathrm{C}_{17: 0}(11.54 \%), \mathrm{C}_{17: 3}$ $(3.61 \%), \mathrm{C}_{18: 0} \quad(38.55 \%)$ and $\mathrm{C}_{19: 0}(17.49 \%)$. The phospholipids consisted of diphosphatidylglycerol, phosphatidylethanolamine, phosphatidylinositol and phospholipids of unknown structure containing glucosamine and represented the type IV phospholipid pattern (Lechevalier et al., 1981).

Physiological characteristics of the strain were tested according to the Streptosporangium standard (Nonomura,

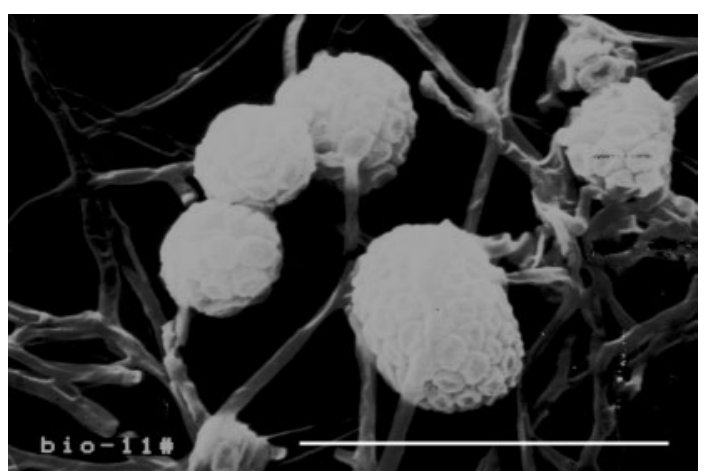

Fig. 1. Scanning electron micrograph of growth of strain HBUM $170018^{\top}$ on ISP3 medium after 14 days at $28^{\circ} \mathrm{C}$. Bar, $10 \mu \mathrm{m}$.
1989). B vitamin requirements were investigated using the method of Zhou \& Cao (1981). The optimal growth temperature of strain HBUM $170018^{\mathrm{T}}$ was $28^{\circ} \mathrm{C}$ and the optimal growth $\mathrm{pH}$ was 7.2. The other results are shown in Table 1 and the species description.

For 16S rRNA gene sequence analysis, determination of $\mathrm{G}+\mathrm{C}$ content and DNA-DNA hybridization, chromosomal DNA was extracted using the procedures described by Marmur (1961) and Kutchma et al. (1998). The $\mathrm{G}+\mathrm{C}$ content was determined by using the method of Mesbah et al. (1989). The DNA was treated with BAL-31 nuclease and alkaline phosphatase and mononucleotides were identified using HPLC. The DNA G $+\mathrm{C}$ content of strain HBUM $170018^{\mathrm{T}}$ was found to be $67.8 \mathrm{~mol} \%$. The initial reassociation-rate method (De Ley et al., 1970) and a spectrophotometer (model CE9500; Cecil Instruments) equipped with a programmable melting-temperature control unit were used for determining the degree of DNA-DNA hybridization. The analysis was repeated three times (standard deviation $0.5-0.8 \%$ ) and mean values were obtained.

Table 1. Comparison of physiological characteristics of strain HBUM $170018^{\top}$ and related strains

Strains: 1, HBUM $170018^{\mathrm{T}}$; 2, S. album DSM $43023^{\mathrm{T}}$; 3, S. roseum DSM $43021^{\mathrm{T}}$; 4, S. vulgare DSM $43802^{\mathrm{T}}$. All strains were positive for the utilization of cellobiose, dextrin and D-mannitol and negative for the utilization of melibiose. All strains were positive for the hydrolysis of citrate, hippurate and urea and negative for the hydrolysis of adenine, casein, cytosine, hypoxanthine, starch, L-tyrosine, uridine and xanthine. All strains required B vitamins for growth. Data are from this study.

\begin{tabular}{|c|c|c|c|c|}
\hline Characteristic & 1 & 2 & 3 & 4 \\
\hline \multicolumn{5}{|l|}{ Utilization of: } \\
\hline L-Arabinose & + & + & - & - \\
\hline Erythrose & + & - & - & - \\
\hline D-Fructose & + & + & - & + \\
\hline D-Galactose & - & + & - & + \\
\hline Inositol & + & - & - & - \\
\hline D-Mannose & + & + & - & + \\
\hline Maltose & + & + & - & - \\
\hline Raffinose & - & + & - & - \\
\hline Rhamnose & + & + & - & - \\
\hline Sorbitol & - & + & + & - \\
\hline Sorbose & - & - & + & + \\
\hline D-Xylose & + & - & - & + \\
\hline Gelatin liquefaction & + & + & - & - \\
\hline Nitrite from nitrate & + & - & + & - \\
\hline Cellulose degradation & + & - & - & + \\
\hline \multicolumn{5}{|l|}{ Hydrolysis of: } \\
\hline Lactate & + & - & - & + \\
\hline Malate & - & - & + & + \\
\hline Oxalate & + & - & - & + \\
\hline Salicylic acid & - & + & - & - \\
\hline
\end{tabular}


The 16S rRNA gene was amplified using a PCR with Taq DNA polymerase (Sangon) according to the methods of Zhang et al. (2008), with universal primers $27 \mathrm{f}$ (Escherichia coli positions 8-27; 5'-GAGTTTGATCCTGGCTCAG-3') and $1525 \mathrm{r} \quad\left(E\right.$. coli positions 1525-1545; $5^{\prime}$ AGAAAGGAGGTGTACCAGCC-3') (Lane et al., 1985). The PCR product was purified and then sequenced at the Beijing Genomics Institute, Chinese Academy of Sciences.

The almost-complete $16 \mathrm{~S}$ rRNA gene sequence determined for strain HBUM $170018^{\mathrm{T}}$ (1432 nt) was aligned with the corresponding sequences of representative reference strains from the genus Streptosporangium (retrieved from the GenBank database) using CLUSTAL w, version $1.4 \mathrm{~b}$ (Thompson et al., 1994). The evolutionary tree was inferred using the neighbour-joining method (Saitou \& Nei, 1987). Evolutionary distance matrices were generated according to the algorithms of the neighbour-joining, maximum-parsimony (Eck \& Dayhoff, 1966) and minimum-evolution (Rzhetsky \& Nei, 1992) methods and the robustness of the tree topology from the neighbour-joining data was evaluated by means of bootstrap analysis (Felsenstein, 1993) (based on 1000 resamplings) using the MEGA4 package (Tamura et al., 2007). It was evident from the phylogenetic tree (Fig. 2) that strain HBUM $170018^{\mathrm{T}}, S$. album DSM $43023^{\mathrm{T}}$, S. roseum DSM $43021^{\mathrm{T}}$ and S. vulgare DSM $43802^{\mathrm{T}}$ clustered into a branch. Sequence-similarity calculations obtained after a neighbour-joining analysis indicated that the closest relatives of strain HBUM $170018^{\mathrm{T}}$ were S. roseum DSM $43021^{\mathrm{T}}(99.90 \%)$, S. album DSM $43023^{\mathrm{T}}(99.90 \%)$ and S. vulgare DSM $43802^{\mathrm{T}}(99.90 \%)$. The DNA-DNA relatedness of strain HBUM $170018^{\mathrm{T}}$ with respect to related strains was found to range from 23.28 to $64.26 \%$ (Supplementary Table S2). These values were below the value of $70 \%$ recommended by Wayne et al. (1987) for the assignment of strains to the same species.

In summary, phenotypic and genotypic characteristics showed that HBUM $170018^{\mathrm{T}}$ is a member of the genus
Streptosporangium. However, morphological, physiological and chemotaxonomic characteristics serve to differentiate this strain from recognized species of the genus. DNADNA hybridization is the standard used for species designation: the cut-off point indicating members of the same species is at $\geqslant 70 \%$ DNA-DNA relatedness. Low DNA-DNA relatedness values $(<70 \%)$ were determined between strain HBUM $170018^{\mathrm{T}}$ and type strains of members of the genus Streptosporangium. On the basis of the above-mentioned phenotypic and genotypic data, therefore, strain HBUM $170018^{\mathrm{T}}$ represents a novel species of the genus Streptosporangium, for which the name Streptosporangium canum sp. nov. is proposed.

\section{Description of Streptosporangium canum sp. nov.}

Streptosporangium canum (ca'num. L. neut. adj. canum whitish grey).

Gram-positive-staining. The colour of the aerial mycelium is whitish grey on ISP3 medium, ISP5 medium and Czapek agar. Grows well on various media. No amethyst, diffusible pigments are produced. The sporangia are spherical and 3$6 \mu \mathrm{m}$ in diameter. Spores are rod-shaped $(0.5-1.0 \mu \mathrm{m}$ long) and non-motile. Optimal growth at $28{ }^{\circ} \mathrm{C}$ and pH 7.2. Cell walls contain meso-diaminopimelic acid. Whole-cell hydrolysates contain madurose, glucose, rhamnose and ribose (type III/B). The menaquinones consist mainly of MK-9 $\left(\mathrm{H}_{4}\right)$ and MK- $9\left(\mathrm{H}_{2}\right)$. The major cellular fatty acids are $C_{16: 0}, C_{17: 0}, C_{17: 3}, C_{18: 0}$ and $C_{19: 0}$. The polar lipids consist of diphosphatidylglycerol, phosphatidylinositol, phosphatidylethanolamine and phospholipids of unknown structure containing glucosamine (type IV phospholipid pattern). The DNA G $+\mathrm{C}$ content of the type strain is $67.8 \mathrm{~mol} \%$. L-Arabinose, cellobiose, D-fructose, Dmannose, D-mannitol, D-xylose, erythrose, rhamnose, maltose, inositol and dextrin are utilized, but D-galactose, sorbitol, sorbose, melibiose and raffinose are not utilized. Positive for cellulose degradation and negative for starch

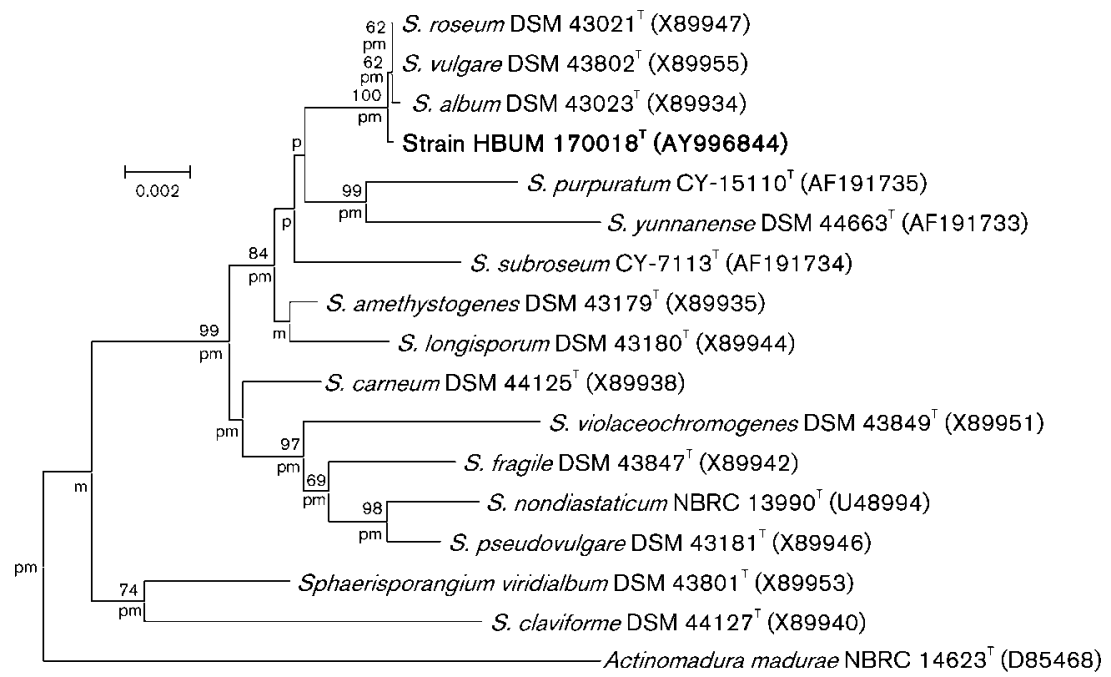

Fig. 2. Neighbour-joining phylogenetic tree, based on almost-complete 16S rRNA gene sequences, showing the relationship between strain HBUM $170018^{\top}$ and members of the genus Streptosporangium. Numbers at nodes indicate bootstrap percentages (based on 1000 resampled datasets); only values greater than $50 \%$ are given. The sequence of Actinomadura madurae NBRC $14623^{\top}$ was used as the outgroup. Clades also recovered by the minimum-evolution method are labelled ' $m$ ' and clades also recovered by both the maximum-parsimony method are labelled ' $p$ '. Bar, 0.002 substitutions per nucleotide position. 
degradation. Urea, citrate, hippurate, lactate and oxalate are hydrolysed. Malate, salicylic acid, adenine, xanthine, cytosine, hypoxanthine, casein, L-tyrosine and uridine are not hydrolysed. Positive for reduction of nitrate and liquefaction of gelatin. B vitamins are required for growth.

The type strain, strain HBUM $170018^{\mathrm{T}}\left(=7177^{\mathrm{T}}=\mathrm{DSM}\right.$ $45034^{\mathrm{T}}=$ CGMCC $4.2126^{\mathrm{T}}$ ), was isolated from soil from Hebei Province, China.

\section{Acknowledgements}

The work was supported by the National Natural Science Foundation of China (grant no. 30270002) and the Program for Basic Microorganisms Resources Arranging, Integrating and Sharing Platform Construction of National Science and Technology Board, China (grant no. 2006DKA21206).

\section{References}

Becker, B., Gordon, R. E., Lechevalier, H. A. \& Lechevalier, M. P. (1964). Rapid differentiation between Nocardia and Streptomyces by paper chromatography of whole cell hydrolysates. Appl Microbiol 12, 421-423.

Collins, M. D. (1985). Isoprenoid quinone analysis in classification and identification. In Chemical Methods in Bacterial Systematics, pp. 267-287. Edited by M. Goodfellow \& D. E. Minnikin. London: Academic Press.

Couch, J. N. (1955). A new genus and family of the Actinomycetales, with a revision of the genus Actinoplanes. J Elisha Mitchell Sci Soc 71, $148-155$.

De Ley, J., Cattoir, H. \& Reynaerts, A. (1970). The quantitative measurement of DNA hybridization from renaturation rates. Eur $J$ Biochem 12, 133-142.

Eck, R. V. \& Dayhoff, M. O. (1966). Atlas of Protein Sequence and Structure. Silver Springs, MD: National Biomedical Research Foundation.

Felsenstein, J. (1993). PHYLIP (phylogenetic inference package), version 3.5c. Distributed by the author. Department of Genome Sciences, University of Washington, Seattle, USA.

linuma, S., Yokota, A. \& Kanamura, T. (1996). New subspecies of the genus Streptosporangium, Streptosporangium amethystogenes subsp. fukuiense subsp. nov. Actinomycetologica 10, 35-42.

Jones, K. L. (1949). Fresh isolates of actinomycetes in which the presence of sporogenous aerial mycelia is a fluctuating characteristic. J Bacteriol 57, 141-146.

Kawamoto, I., Takasawa, S., Okachi, R., Kohakura, M., Takahashi, I. \& Nara, T. (1975). A new antibiotic victomycin (XK 49-1-B-2). I. Taxonomy and production of the producing organism. $J$ Antibiot (Tokyo) 28, 358-365.

Kutchma, A. J., Roberts, M. A., Knaebel, D. B. \& Crawford, D. L. (1998). Small-scale isolation of genomic DNA from Streptomyces mycelia or spores. Biotechniques 24, 452-456.

Kuykendall, L. D., Roy, M. A., O’Neill, J. \& Devine, T. E. (1988). Fatty acids, antibiotic resistance, and deoxyribonucleic acid homology groups of Bradyrhizobium japonicum. Int J Syst Bacteriol 38, 358-361.

Lane, D. J., Pace, B., Olsen, G. J., Stahl, D. A., Sogin, M. L. \& Pace, N. R. (1985). Rapid determination of $16 \mathrm{~S}$ ribosomal RNA sequences for phylogenetic analyses. Proc Natl Acad Sci U S A 82, 6955-6959.
Lechevalier, H. A. \& Lechevalier, M. P. (1980). The chemotaxonomy of actinomycetes. In Actinomycete Taxonomy (Special Publication 6), pp. 227-291. Edited by A. Dietz \& J. Thayer. Arlington, VA: Society for Industrial Microbiology.

Lechevalier, M. P., Stern, A. E. \& Lechevalier, H. A. (1981). Phospholipids in the taxonomy of actinomycetes. In Actinomycetes, pp. 111-116. Edited by K. P. Schaal \& G. Pulverer. New York: Gustav Fischer.

Marmur, J. (1961). A procedure for the isolation of deoxyribonucleic acid from microorganisms. J Mol Biol 3, 208-218.

Mertz, F. P. \& Yao, R. C. (1990). Streptosporangium carneum sp. nov. isolated from soil. Int J Syst Bacteriol 40, 247-253.

Mesbah, M., Premachandran, U. \& Whitman, W. B. (1989). Precise measurement of the $\mathrm{G}+\mathrm{C}$ content of deoxyribonucleic acid by highperformance liquid chromatography. Int J Syst Bacteriol 39, 159-167.

Miller, L. T. (1982). Single derivatization method for routine analysis of bacterial whole-cell fatty acid methyl esters, including hydroxy acids. J Clin Microbiol 16, 584-586.

Nonomura, H. (1989). Genus Streptosporangium Couch 1955, $148^{\mathrm{AL}}$. In Bergey's Manual of Systematic Bacteriology, vol. 4, pp. 2545-2551. Edited by S. T. Williams, M. E. Sharpe \& J. G. Holt. Baltimore: Williams \& Wilkins.

Nonomura, H. \& Ohara, Y. (1960). Distribution of the actinomycetes in soil. V. The isolation and classification of the genus Streptosporangium. J Ferment Technol 38, 405-409.

Nonomura, H. \& Ohara, Y. (1969). Distribution of the actinomycetes in soil. VII. A culture method effective for both preferential isolation and enumeration of Microbispora and Streptosporangium strains in soil. Part 2. Classification of the isolates. J Ferment Technol 47, 701709.

Petrolini, B., Quaroni, S., Sardi, P., Saracchi, M. \& Andriollo, N. (1992). A sporangiate actinomycete with unusual morphological features: Streptosporangium claviforme sp. nov. Actinomycetes 3, 4550.

Research Group of Actinomycetes (1970). Manual of Determinative Actinomycetes. Beijing: Science Press.

Rzhetsky, A. \& Nei, M. (1992). A simple method for estimating and testing minimum evolution trees. Mol Biol Evol 9, 945-967.

Saitou, N. \& Nei, M. (1987). The neighbor-joining method: a new method for reconstructing phylogenetic trees. Mol Biol Evol 4 , 406-425.

Schäfer, D. (1969). Eine neue Streptosporangium-Art aus türkischer Steppenerde. Arch Mikrobiol 66, 365-373 (in German).

Shearer, M. C., Colman, P. M. \& Nash, C. H., III (1983). Streptosporangium fragile sp. nov. Int J Syst Bacteriol 33, 364-368.

Shirling, E. B. \& Gottlieb, D. (1966). Methods for characterization of Streptomyces species. Int J Syst Bacteriol 16, 313-340.

Tamura, K., Dudley, J., Nei, M. \& Kumar, S. (2007). MEGA4: molecular evolutionary genetics analysis (MEGA) software version 4.0. Mol Biol Evol 24, 1596-1599.

Thompson, J. D., Higgins, D. G. \& Gibson, T. J. (1994). CLUSTAL W: improving the sensitivity of progressive multiple sequence alignment through sequence weighting, position-specific gap penalties and weight matrix choice. Nucleic Acids Res 22, 4673-4680.

Waksman, S. A. (1967). The Actinomycetes. A Summary of Current Knowledge. New York: Ronald Press.

Wayne, L. G., Brenner, D. J., Colwell, R. R., Grimont, P. A. D., Kandler, O., Krichevsky, M. I., Moore, L. H., Moore, W. E. C., Murray, R. G. E. \& other authors (1987). International Committee on Systematic Bacteriology. Report of the ad hoc committee on reconciliation of approaches to bacterial systematics. Int J Syst Bacteriol 37, 463-464. 
Zhang, L., Jiang, C. \& Chen, W. (2002). Streptosporangium subroseum sp. nov., an actinomycete with an unusual phospholipid pattern. Int $J$ Syst Evol Microbiol 52, 1235-1238.

Zhang, L.-P., Jiang, C.-L. \& Chen, W.-X. (2005). Streptosporangium yunnanense sp. nov. and Streptosporangium purpuratum sp. nov., from soil in China. Int J Syst Evol Microbiol 55, 719-724.
Zhang, X., Zhang, L.-P., Yang, R., Shi, N., Lu, Z., Chen, W. X., Jiang, C.-L. \& Xu, L.-H. (2008). Nocardiopsis ganjiahuensis sp. nov., isolated from a soil of Ganjiahu in China. Int J Syst Evol Microbiol 58, 195199.

Zhou, J. C. \& Cao, Y. Z. (1981). Nutrient requirements of the fastgrowing rhizobia. J Huazhong Agric Coll 3, 44-56 (in Chinese). 